\title{
New trends in the ovarian cancer treatment
}

\section{Nowe trendy w leczeniu raka jajnika}

\author{
Agnieszka Marczak, Barbara Bukowska \\ Department of Thermobiology, Faculty of Biology and Environmental Protection, University of Lodz; \\ Head of Department: Aneta Koceva-Chyła MD, PhD
}

Przegląd Menopauzalny 2013; 6: 489-492

\section{Summary}

Ovarian cancer is the fifth most lethal malignancy in women. The standard treatment of this disease is chemotherapy which is, however, often inefficient. The failure of chemotherapy is due to the developing multidrug resistance and the presence of cancer stem cells. This article describes research on new drugs, which can overcome these limitations. Some of the substances which are effective in cancer cells resistant to the standard approach are bisintercalating anthracyclines and epothilones. One of the bisanthracyclines is WP 631, which is more effective than commonly used first-generation anthracyclines, even on cells resistant to cisplatin or doxorubicin. In turn, epothilones have a similar mechanism of action as taxanes. They stabilize microtubules and consequently perturb mitosis. Both WP 631 and epothilones appear to be hopeful candidates to break multidrug resistance because of their low affinity for P-glycoprotein - the efflux pump for drugs. Substances, which effectively eliminate cancer stem cells include metformin, Müllerian inhibiting substance, and salinomycin. Metformin has a proapoptotic activity and exhibits synergism with cisplatin - a chemotherapeutic agent used in ovarian cancer treatment. Müllerian inhibiting substance perturbs the cell cycle, while salinomycin inhibits proliferation and induces apoptosis in the ovarian cancer cells.

The search for new drugs effective in the ovarian cancer treatment, especially in cases resistant to current forms of therapy, remains a challenging priority.

Key words: ovarian cancer, cancer stem cells, multidrug resistance.

\section{Streszczenie}

Nowotwór jajnika zajmuje piąte miejsce pod względem częstości zgonów z powodu chorób nowotworowych u kobiet. Najpowszechniej stosowaną metodą leczenia jest w tym przypadku chemioterapia, jednak jest ona niewystarczająco skuteczna. Niepowodzenie chemioterapii związane jest m.in. z rozwijającą się opornością wielolekową (multidrug resistance - MDR) oraz obecnością macierzystych komórek nowotworowych. Niniejszy artykuł mówi o badaniach dotyczących nowych leków, które przeciwdziałałyby tym ograniczeniom. Do substancji, które są skuteczne w komórkach opornych na standardowo stosowane leczenie, można zaliczyć bisinterkalacyjne antracykliny oraz epotilony. Przedstawicielem bisantracyklin jest WP 631, który jest skuteczniejszy niż powszechnie stosowane antracykliny pierwszej generacji. Dotyczy to także komórek opornych na cisplatynę czy doksorubicynę. Z kolei epotilony to związki o mechanizmie działania zbliżonym do taksanów. Stabilizują one mikrotubule, co zaburza proces mitozy. Zarówno WP 631, jak i epotilony dają nadzieję na przełamanie MDR ze względu na wykazywanie małego powinowactwa do glikoproteiny $P$, transportera, który wyrzuca leki poza komórkę. Z kolei do substancji skutecznych w eliminowaniu macierzystych komórek nowotworowych należą: metformina, substancja hamująca Müllera oraz salinomycyna. Metformina działa proapoptotycznie, ponadto wykazuje synergizm działania z cisplatyną - chemioterapeutykiem stosowanym w terapii raka jajnika. Substancja hamująca Müllera zaburza cykl komórkowy, natomiast salinomycyna hamuje proliferację oraz indukuje apoptozę w komórkach raka jajnika.

Poszukiwanie nowych leków, skutecznych w terapii raka jajnika, zwłaszcza przypadków opornych na inne metody leczenia, powinno być priorytetem.

Słowa kluczowe: rak jajnika, komórki macierzyste nowotworu, oporność wielolekowa. 


\section{Introduction}

There are many reasons of failure of ovarian cancer therapy, but the most important ones are the development of multi-drug resistance (MDR) to currently used chemotherapeutic agents [1] and the presence of cancer stem cells (CSCS). They constitute a small population of undifferentiated cells (usually $0.01-1.0 \%$ of the pool of cancer cells), with ability to self-renew and thereby responsible for relapse and metastasis [2]. The search for new drugs able to overcome those limitations has recently become a priority.

\section{Compounds effective in cells resistant to standard treatment}

The anthracycline antibiotics have been used in chemotherapy for many years. They exhibit a complex mechanism of action, which involves intercalation to DNA, generation of free radicals, inhibition of topoisomerase I and II activity, as well as apoptosis induction $[3,4]$. However, due to their insufficient efficacy and serious side effects, new derivatives characterized by a better activity profile are being searched. A novel group of bisintercalating anthracyclines, whose representative is WP 631, offers the hope for more efficient treatment. It is composed of two molecules of daunorubicin (DNR) symmetrically linked with a $p$-xylenyl linker. In comparison to monomeric forms, it indicates a greater ability to bind DNA. Numerous studies demonstrated that WP 631 is more efficient than commonly used firstgeneration anthracyclines. But what is the most promising is that WP 631 gives hope for overcoming the multidrug resistance. This compound has low affinity for the membrane transporters responsible for drug efflux [5], and especially for P-glycoprotein (P-gp).

It has been indicated that the new analogue is more cytotoxic against Jurkat T lymphocytes than DNR due to the induction of $\mathrm{G} 2 / \mathrm{M}$ arrest [6]. It has also been proven that WP 631 is more toxic than doxorubicin (DOX). It was found that the new bisanthracycline analogue induced mainly apoptosis in SKOV-3 cancer cell line, which shows resistance, among others to cisplatin or adriamycin. In comparison to DOX [7], the novel derivative has also a higher ability to generate free radicals. These findings suggest that WP 631 could be an effective alternative to older generations of anthracyclines.

Another group of compounds giving hope to patients for whom standard chemotherapy is ineffective are epothilones, discovered in 1987. They were isolated from myxobacterium Sorangium cellulosum and classified as antifungal substances [8]. Because of too high toxicity they could not be used as antifungal agents, however they have come into use in anticancer therapy. Naturally occurring epothilones are epothilone $\mathrm{A}$ and epothilone $\mathrm{B}$. They are 16-membered macrolides and are subtly differ- ent in their structure: epothilone B has an extra methyl group at the epoxide moiety. Their mechanism of action is similar to taxanes - a group of drugs, used for many years in therapy of various types of cancers, including ovarian cancer. Both groups are microtubule stabilizers; they prevent microtubule depolarization, which causes abnormalities in mitosis [9]. Both classes of drugs bind to $\beta$-tubulin subunit. Unlike taxanes, epothilones efficiently inhibit the growth of cancer cells with P-glycoprotein overexpression, what could translate to a higher efficacy in multi-drug resistance cancer treatment [10]. Because of the greater ability to tubulin, they stronger induce the process of tubulin dimerization [11]. The preponderance of epothilones over taxanes has also been indicated in in vitro studies. It was observed that epothilone $B$ is much more cytotoxic than paclitaxel (PTX) in SKOV-3 ovarian cancer cell line. $I C_{50}$ value obtained for Epo B was $27.5 \mathrm{nM}$, for Epo A - 20.4 nM, while PTX induced the same effect only at the concentration of $126.2 \mathrm{nM}$. Epothilones also induced apoptosis and necrosis stronger than PTX. Those alternations were partly blocked by an antioxidant $N$-acetylcysteine (NAC), which suggests that reactive oxygen species play an important role in the apoptosis induced by applied drugs. Epothilone B decreased the membrane potential more than PTX. The ability of epothilones to overcome the multi-drug resistance may be due to lower affinity of the drug to the p-glycoprotein as compared to paclitaxel [12].

In view of higher effectiveness in comparison to previous analogues, both WP 631 and epothilone B, may find use in the cancer treatment. In particular, in the case of the development of multi-drug resistance or the treatment of disorders, such as ovarian cancer, in which drugs used so far did not show adequate activity.

\section{Drugs affecting cancer stem cells}

A characteristic feature of cancer stem cells is the presence of specific markers facilitating their identification and isolation. The role of such markers could be played by the molecules belonging to the CD group (Cluster of Differentiation) as well as cytoprotective enzymes or $A B C$ transporters. The distinctive markers for ovarian cancer are CD133, CD117, CD44, CD24 and ALDH.

CD133 is a transmembrane glycoprotein encoded by the CD133/Prom-1 gene. It occurs on the surface of the many stem cells, including the cancer stem cells. Ovarian cancers in which CD133 is expressed are characterized by a higher capacity of proliferation and selfrenewal $[13,14]$. CD44 is a receptor for hyaluronic acid and, similar to CD133, is a marker typical of a different type of cancer. In turn, CD117 is expressed in many kinds of stem cells, including ovarian cancer stem cells. Those two markers are often co-expressed [15]. Their presence is associated with an increased chemoresistance and is responsible for the ability to initiate and 
promote cancer. CD24 is also a glycoprotein characteristic of a variety of types of cancer. It has been suggested that it may affect the expression of Nanog factor, distinctive for stem cells, and consequently lead to cancer initiation in the ovaries [16]. A typical marker of cancer stem cells is also the aldehyde dehydrogenase activity (ALDH). CSCs, in which this enzyme exhibits its activity, have greater capacity to initiate cancer and also more intensified angiogenesis [17].

The metabolism of CSCs is different from other cancer cells metabolism, which results in their resistance to the conventional therapy - radiotherapy, chemotherapy, surgical treatment, but also immunotherapy or gene therapy. These methods of treatment affect only differentiated cells, rapidly dividing, which leads to a reduction in the tumor mass. However, cancer stem cells are being destroyed in a less effective way, which results in a rapid relapse [18].

Those suggestions shed new light on the cancer treatment. Only the therapy that thoroughly eliminates cancer stem cells could turn out to be successful and this is why new substances affecting CSCS are being searched for. These new substances include metformin, Müllerian inhibiting substance and salinomycin.

\section{Metformin}

Metformin is an oral antidiabetic drug, used in the treatment of type 2 diabetes in adults, in particular in obese patients. It is applied either in monotherapy or in a combination with other oral antidiabetic agents or insulin [19]. However, it was demonstrated that metformin affects also cancer stem cells, what was first observed in the case of breast cancer. Hirsch et al. indicated that metformin inhibits neoplastic transformation and kills cancer stem cells in four genetically different types of breast cancer at the concentrations which do not affect the intact cells. Moreover, in vivo and in vitro synergism between metformin and doxorubicin was determined [20]. In turn, Vazquez-Martin et al. demonstrated that metformin is synergistic with trastuzumab, destroying CSCs in HER2-positive breast cancer [21].

Metformin acts in a similar manner also in ovarian cancers. Gotlieb et al. investigated the effect of metformin on two ovarian cancer cell lines, OVCAR-3 and OVCAR-4. It was observed that the drug inhibits cell proliferation in both cell lines. Their research also confirmed that metformin potentiates cytotoxicity of cisplatin a chemotherapeutic agent commonly used in the ovarian cancer treatment - in OVCAR-3 cell line [22]. Other in vitro studies on OVCAR-3 and OVCAR-4 cell lines demonstrated the proapoptotic properties of metformin, as the inhibition of antiapoptotic $\mathrm{Bcl}-2$ proteins ( $\mathrm{Bcl}-2, \mathrm{BCl}$ $\mathrm{xL}, \mathrm{Mcl}-1$ ) and activation of proapoptotic proteins (Bax, Bas) were noticed. Some changes characteristic of apoptosis, such as enhanced activity of caspase- 3 and -7 and phosphatidylserine externalization were observed [23]. Moreover, the most crucial fact is that metformin targets not only the overall pool of ovarian cancer cells, but also the cancer stem cells. Shank et al. examined the impact of metformin on SKOV-3 and A2780 cell lines. The cell proliferation was inhibited in both cell lines. The combined effect of metformin and cisplatin on cell multiplication has also been evaluated. Both in cisplatinsensitive cells (A2780) and cells resistant to this chemotherapeutic agent (SKOV-3), the decreased cell survival was observed, which suggests that those two drugs act synergistically. Also the effect of metformin on CSCs was established. It was noted that metformin reduces the number of aldehyde dehydrogenase (ALDH) expressing cells. An increased ALDH activity is a marker typical of ovarian cancer. Also in vivo metformin action was studied. Human ovarian cancer cells were transplanted into mice with impaired immune response. The animals were then treated with cisplatin, metformin or a combination of those drugs. A non-significant decrease in tumor growth (in comparison to untreated controls) was observed after cisplatin alone and metformin alone. In contrast, the combination of chemotherapeutics restricted tumor growth more notably, when compared to untreated mice and those treated with cisplatin and metformin in monotherapy. It was also indicated that metformin in combination with chemotherapy reduces angiogenesis in $\mathrm{ALDH}(+)$ cells [24].

\section{Müllerion inhibiting substance}

Another substance targeting ovarian cancer stem cells is Müllerian inhibiting substance (MIS). It is secreted by Sertoli cells during embryogenesis. This compound inhibits the development of Müllerian ducts, from which, otherwise, uterus and fallopian tubes would be formed.

Meirelles et al. investigated the impact of MIS on ovarian cancer cells expressing markers characteristic of ovarian CSCS (CD44, CD24 and Ecam), and not having E-cadherin (3+Ecad-). The fluorescence activated cell sorting (FACS) was performed in order to isolate 3+Ecad- populations from several cell lines (HOSE-4, HOSE-6, OVCAR-3, OVCAR-5, MOVCAR-7, MOVCAR-8, SKOV-3, IGROV-1). It was observed that MIS significantly inhibited the colony forming of 3+Ecad-cells separated from OVCAR-5 cell line. Moreover, it was noticed that MIS treatment correlated with cell cycle G1 arrest of 3+Ecad- OVCAR-5 cells. Furthermore, MIS treatment increased the activity of cyclin-dependent kinases inhibitors, p15 and p16, which was tested in MOVCAR-7 cells, as p15 and p16 are often mutated in many human ovarian cancer cell lines. The increased concentration of microRNA-binding protein, LIN28 (in comparison to lines isolated from normal human ovarian surface epithelium - HOSE-4 and HOSE-6), was also observed in 
the tested human ovarian cancer cell lines. This protein regulates the expression of cell cycle-related genes and controls the CSCs differentiation and self-renewal [25].

\section{Sallinomycin}

Salinomycin is an antibiotic exhibiting both antibacterial and antiparasitic activity. The studies of Zhang et al. indicated that salinomycin could selectively affect ovarian CSCs, both in vitro and in vivo. In in vitro studies it was noticed that this compound inhibits proliferation of OV2008 cells and induces apoptosis, most likely due to the increased activity of p38 mitogen-activation protein kinase (p38 MAPK). In turn, in vivo salinomycin inhibited the growth of ovarian xenograft tumors in mice with impaired immune response [26].

\section{Summary}

In the age of raised ovarian cancer morbidity, together with the lack of satisfactory methods of its early diagnosis, every new drug that increases curability especially in the advanced stages of this disease, appears to be "worth its weight in gold". The compounds, presented in this paper, are very promising, as they affect the very important molecular targets. In particular, destroying cancer stem cells appears to be the most valuable. The chemotherapeutic agents used currently affect mainly the cells forming tumor mass, which, as rapidly dividing, are prone to the cytostatic drugs. However, these substances do not affect "the core", which is a subpopulation of cancer stem cells. This results in a primary tumor renewal and therefore forces to undergo another treatment. The destruction of this new cancer cells source may lead to the eradication of the tumor. The compounds, which overcome multidrug resistance - the main reason of standard chemotherapy failure - are also valuable. Currently tested new drugs, such as epothilones or bisintercalating compound, WP 631 (a member of anthracyclines with a low affinity for transporters excluding drugs from the cell), could replace the older analogues. However, further research and searching for a relationship between the mechanisms of action of the individual compounds are needed. It will enable selection of those which act synergistically and thereby are effective against ovarian cancer, even if the disease is advanced or standard chemotherapy is inefficient.

This study was supported by Grant No. N N405 100939 of the Ministry of Science and Higher Education.

\section{References}

1. Yang H, Chen B. CD147 in ovarian and other cancers, Int J Gynecol Cancer 2013; 23: 2-8.
2. Burgos-Ojeda D, Rueda BR, Buckanovich RJ. Ovarian cancer stem cell markers: Prognostic and therapeutic implications, Cancer Lett 2012; 322: 1-7.

3. Mutschler E., Antybiotyki działające cytostatycznie. In: Farmakologia i toksykologia. Buczko W (eds.). Wydawnictwo MedPharm, Wrocław 2010; 971-3.

4. Dragojew S, Marczak A, Maszewski J, et al. The induction of apoptosis by daunorubicin and idarubicin in human trisomic and diabetic fibroblasts. Cell Mol Biol Lett 2008; 13: 182-94.

5. Brooks TA, O'Loughlin KL, Minderman H, et al. The 4'-O-benzylated doxorubicin analog WP744 overcomes resistance mediated by P-glycoprotein, multidrug resistance protein and breast cancer resistance protein in cell lines and acute myeloid leukemia cells. Invest New Drugs 2007; 25: 115-22.

6. Villamarín S, Ferrer-Miralles N, Mansilla S, et al. Induction of G(2)/M arrest and inhibition of c-myc and p53 transcription by WP631 in Jurkat T lymphocytes. Biochem Pharmacol 2002; 63: 1251-8.

7. Rogalska A, Gajek A, Szwed M, et al. The role of reactive oxygen species in WP 631-induced death of human ovarian cancer cells: A comparison with the effect of doxorubicin. Toxicol In Vitro 2011; 25: 1712-20.

8. Lee JJ, Swain SM. The epothilones - translating from the laboratory to the clinic. Clin Cancer Res 2008; 14: 1618-24.

9. Cheng KL, Bradley T, Budman DR. Novel microtubule-targeting agents the epothilones. Biologics 2008; 2: 789-811.

10. Lee FY, Smykla R, Johnston K, et al. Preclinical efficacy spectrum and pharmacokinetics of ixabepilone. Cancer Chemother Pharmacol 2009; 63: 201-12.

11. Kumar A, Heise H, Blommers MJ, et al. Interaction of epothilone B (patupilone) with microtubules as detected by two-dimensional solid-state NMR spectroscopy. Angew Chem Int Ed Engl 2010; 49: 7504-7.

12. Rogalska A, Marczak A, Gajek A, et al. Induction of apoptosis in human ovarian cancer cells by new anticancer compounds, epothilone A and B. Toxicol In Vitro 2013; 27: 239-49.

13. Ferrandina G, Martinelli E, Petrillo M, et al. CD133 antigen expression in ovarian cancer. BMC Cancer 2009; 9: 221.

14. Baba T, Convery PA, Matsumura N, et al. Epigenetic regulation of CD133 and tumorigenicity of CD133+ ovarian cancer cells. Oncogene 2009; 28: 209-18.

15. Bapat SA, Mali AM, Koppikar CB, Kurrey NK. Stem and progenitor-like cells contribute to the aggressive behavior of human epithelial ovarian cancer. Cancer Res 2005; 65: 3025-9.

16. Lee TK, Castilho A, Cheung VC, et al. CD24(+) liver tumor-initiating cells drive self-renewal and tumor initiation through STAT3-mediated NANOG regulation. Cell Stem Cell 2011; 9: 50-63.

17. Silva IA, Bai S, McLean K, et al. Aldehyde dehydrogenase in combination with CD133 defines angiogenic ovarian cancer stem cells that portend poor patient survival. Cancer Res 2011; 71: 3991-4001.

18. Statkiewicz M, Małecki M. Macierzyste komórki nowotworowe a oporność nowotworów na terapię. Nowotwory 2009; 59: 456-63.

19. Metformax, Charakterystyka Produktu Leczniczego (Centrum Informacji o Leku, available at: leki-informacje.pl).

20. Hirsch HA, Iliopoulos D, Tsichlis PN, Struhl K. Metformin selectively targets cancer stem cells, and acts together with chemotherapy to block tumor growth and prolong remission. Cancer Res 2009; 69: 7507-11.

21. Vazquez-Martin A, Oliveras-Ferraros C, Del Barco S, The anti-diabetic drug metformin suppresses self-renewal and proliferation of trastuzumab-resistant tumor-initiating breast cancer stem cells. Breast Cancer Res Treat 2011; 126: 355-64.

22. Gotlieb WH, Saumet J, Beauchamp MC, et al. In vitro metformin antineoplastic activity in epithelial ovarian cancer. Gynecol Oncol 2008; 110: 246-50.

23. Yasmeen A, Beauchamp MC, Piura E, et al. Induction of apoptosis by metformin in epithelial ovarian cancer: involvement of the Bcl-2 family proteins. Gynecol Oncol 2011; 121: 492-8.

24. Shank JJ, Yang K, Ghannam J, et al. Metformin targets ovarian cancer stem cells in vitro and in vivo. Gynecol Oncol 2012; 127: 390-7.

25. Meirelles K, Benedict LA, Dombkowski D, et al. Human ovarian cancer stem/progenitor cells are stimulated by doxorubicin but inhibited by Mullerian inhibiting substance, Proc Natl Acad Sci U S A 2012; 109: 2358-63.

26. Zhang B, Wang $X$, Cai $F$, et al. Effects of salinomycin on human ovarian cancer cell line OV2008 are associated with modulating P38 MAPK. Tumour Biol 2012; 33: 1855-62. 